WSRC-TR-2003-00322, Rev. 0

Distribution Category: Unlimited

Keywords: DWPF, Sludge Batch

3, Coal, Oxalate, Formate, Nitrate, Oxidation, Reduction

Retention: Permanent

TTR: HLW/DWPF/TTR-02-0017

\title{
CHEMICAL OXYGEN DEMAND (COD) FOR MONITORING REDUCTION-OXIDATION (REDOX) EQUILIBRIUM DURING HIGH LEVEL WASTE (HLW) VITRIFICATION (U)
}

C. M. Jantzen and M.J. Whitaker

Publication Date: April 30, 2004

Approved by:

E.W. Holtzscheiter, Research Manager

Immobilization Technology Section

Westinghouse Savannah River Company

Savannah River Site

Savannah River Technology Center
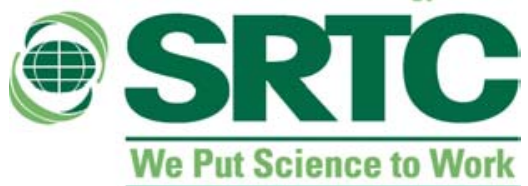

PREPARED FOR THE U.S. DEPARTMENT OF ENERGY UNDER CONTRACT NO. DE-AC09-96SR18500 
This document was prepared in conjunction with work accomplished under Contract No. DE-AC09-96SR18500 with the U. S. Department of Energy.

\section{DISCLAIMER}

This report was prepared as an account of work sponsored by an agency of the United States Government. Neither the United States Government nor any agency thereof, nor any of their employees, makes any warranty, express or implied, or assumes any legal liability or responsibility for the accuracy, completeness, or usefulness of any information, apparatus, product or process disclosed, or represents that its use would not infringe privately owned rights. Reference herein to any specific commercial product, process or service by trade name, trademark, manufacturer, or otherwise does not necessarily constitute or imply its endorsement, recommendation, or favoring by the United States Government or any agency thereof. The views and opinions of authors expressed herein do not necessarily state or reflect those of the United States Government or any agency thereof.

This report has been reproduced directly from the best available copy.

Available for sale to the public, in paper, from: U.S. Department of Commerce, National Technical Information Service, 5285 Port Royal Road, Springfield, VA 22161, phone: (800) 553-6847, fax: (703) 605-6900

email: orders@ntis.fedworld.gov

online ordering: http://www.ntis.gov/help/index.asp

Available electronically at http://www.osti.gov/bridge

Available for a processing fee to U.S. Department of Energy and its contractors, in paper, from: U.S. Department of Energy, Office of Scientific and Technical Information, P.O. Box 62, Oak Ridge, TN 37831-0062,

phone: (865)576-8401,

fax: (865)576-5728

email: $\underline{\text { reports@ adonis.osti.gov }}$ 
WSRC-TR-2003-00322, Rev. 0

Distribution Category: Unlimited

Keywords: DWPF, Sludge Batch

3, Coal, Oxalate, Formate, Nitrate, Oxidation, Reduction

Retention: Permanent

TTR: HLW/DWPF/TTR-02-0017

\section{CHEMICAL OXYGEN DEMAND (COD) FOR MONITORING REDUCTION-OXIDATION (REDOX) EQUILIBRIUM DURING HIGH LEVEL WASTE (HLW) VITRIFICATION (U)}

C. M. Jantzen and M.J. Whitaker

Publication Date: April 30, 2004

Approved by:

E.W. Holtzscheiter, Research Manager

Immobilization Technology Section

Westinghouse Savannah River Company

Savannah River Site

Savannah River Technology Center

Savannah River Siken, SC 29808
Aike
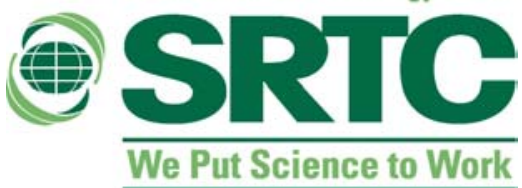

PREPARED FOR THE U.S. DEPARTMENT OF ENERGY UNDER CONTRACT NO. DE-AC09-96SR18500 
This page was intentionally left blank 


\section{WSRC-TR-2003-00322, Rev. 0}

\section{EXECUTIVE SUMMARY}

High-level nuclear waste is being immobilized at the Savannah River Site (SRS) by vitrification into borosilicate glass at the Defense Waste Processing Facility (DWPF). Control of the REDuction/OXidation (REDOX) equilibrium in the DWPF melter is critical for processing high level liquid wastes. Based upon previous research, an acceptable iron REDOX ratio was defined for the DWPF melts as $0.09 \leq \mathrm{Fe}^{2+} / \Sigma \mathrm{Fe} \leq$ 0.33. Controlling the DWPF melter at a REDuction/OXidation (REDOX) equilibrium of $\mathrm{Fe}^{+2} / \Sigma \mathrm{Fe} \leq 0.33$ prevents the potential for metallic and metallic sulfide species to form and accumulate on the floor of the melter. Control of foaming due to deoxygenation of manganic species is achieved by converting 66-100\% of the $\mathrm{MnO}_{2}$ or $\mathrm{Mn}_{2} \mathrm{O}_{3}$ species in a waste feed to $\mathrm{MnO}$ before the waste is fed to the DWPF melter. At the lower redox limit of $\mathrm{Fe}^{+2} / \Sigma \mathrm{Fe} \sim 0.09$ about $99 \%$ of the $\mathrm{Mn}^{+4} / \mathrm{Mn}^{+3}$ is converted to $\mathrm{Mn}^{+2}$. Therefore, the lower REDOX limit eliminates melter foaming from deoxygenation.

Organic and nitrate concentrations in the DWPF melter feed are the major parameters influencing melt REDOX. Organics such as formates act as reductants while nitrates, nitrites, and manganic $\left(\mathrm{Mn}^{+4}\right.$ and $\left.\mathrm{Mn}^{+3}\right)$ species act as oxidants. During melting, the REDOX of the melt pool cannot be measured. Therefore, the $\mathrm{Fe}^{+2} / \Sigma \mathrm{Fe}$ ratio in the glass poured from the melter must be related to melter feed organic and oxidant concentrations to ensure production of a high quality glass without impacting production rate (e.g., from foaming) or melter life (e.g., from metal formation and accumulation).

A new Electron Equivalents REDOX model has been developed for DWPF so that the $\mathrm{Fe}^{+2} / \Sigma \mathrm{Fe}$ ratio can be calculated from feed reductants (formic acid, coal, soluble oxalate, and insoluble oxalate), feed oxidants (nitrate, nitrite, soluble $\mathrm{Mn}^{+4}$, and insoluble $\mathrm{Mn}^{+4}$ ), and $\mathrm{wt} \%$ solids. This requires nine different analyses to be performed. Four of the analyses involve carbon in a variety of oxidation states. The most difficult analysis of a carbon containing species is that of coal. Because of the difficulty and time consuming nature of this analysis it may only be performed once per sludge batch and assumed representative of an entire sludge batch.

A simple analytic technique, known as Chemical Oxygen Demand (COD), was investigated to replace the four carbon species analyses which would leave five analyses to be performed (nitrate, nitrite, soluble manganese, insoluble manganese, and wt\% solids) in order to calculate the $\mathrm{Fe}^{+2} / \Sigma \mathrm{Fe}$ ratio using the Electron Equivalents REDOX model for DWPF. During the course of this study it was determined that the COD response actually measured the sum of all the electron transfers, e.g. the relative contributions of each of the reductants and oxidants. Therefore, only two analyses appear to be needed to predict DWPF REDOX, e.g. COD and SRAT wt\% solids. Fewer analyses will improve the feed acceptability turn around time by substituting a simpler analysis, COD, for multiple analyses, some of which are difficult to perform. Substitution of the COD technique will not compromise the REDOX control strategy currently in use in DWPF. Use of the COD technique is, therefore, considered promising but needs further refinement before it can be implemented in DWPF. 
TABLE OF CONTENTS

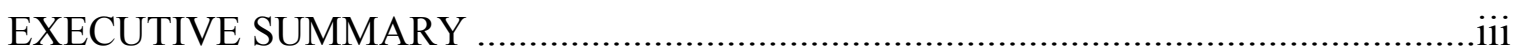

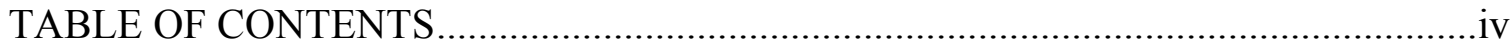

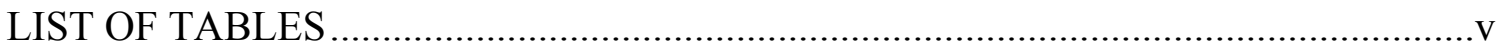

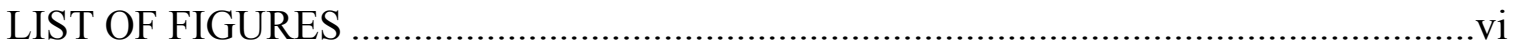

LIST OF ACRONYMS ..........................................................................................

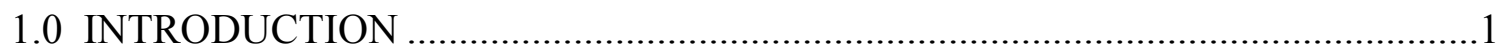

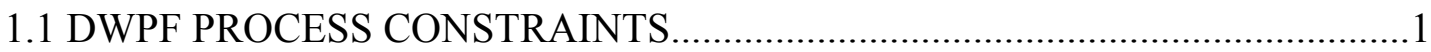

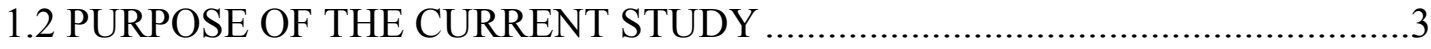

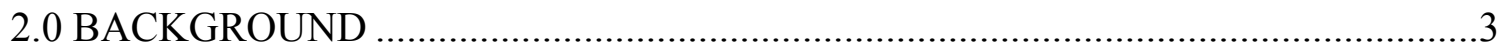

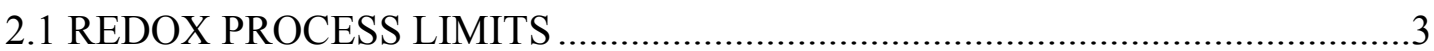

2.2 REDOX MODELING ………………………..............................................

2.3 CHEMICAL OXYGEN DEMAND (COD) MEASURMENTS .............................5

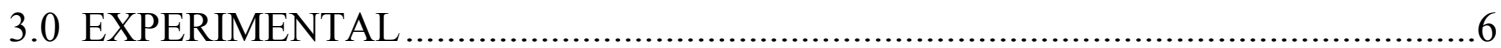

3.1 FEED PREPARATION AND ANALYSES ………......................................6

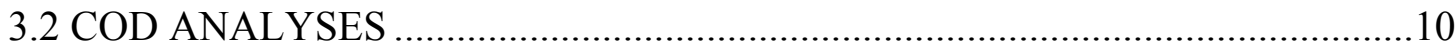

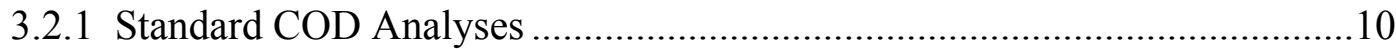

3.2.2 Modified COD Analyses to Accommodate Coal Digestion ...........................12

3.2.3 Effects of Nitric Acid on COD Analyses..................................................14

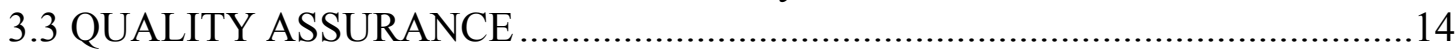

4.0 REGRESSION ANALYSIS OF MODEL CRUCIBLE DATA ……..........................16

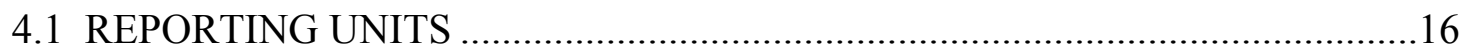

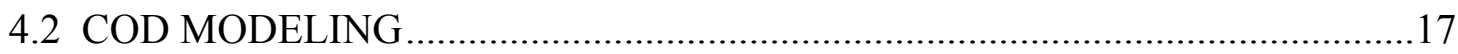

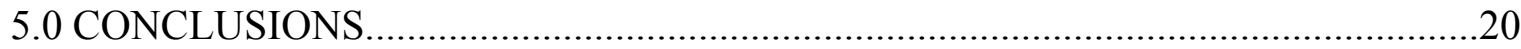




\section{LIST OF TABLES}

Table 1 Adjusted SME Concentrations, Chemical Oxygen Demand, REDOX, and Calcuated Electron Equivalents ............................................................. 8

Table 2 COD Calibration Curve Data.................................................................. 11

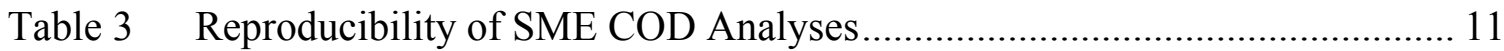

Table 4 Increase in COD Response with Coal Concentration ................................. 12

Table 5 Results of Various Digestion Times on COD Response ............................ 13

Table 6 Precision of Modified COD Method to Accommodate Coal Digestion......... 13

Table $7 \quad \mathrm{HNO}_{3}$ Effects on COD Analyses .......................................................... 15 


\section{LIST OF FIGURES}

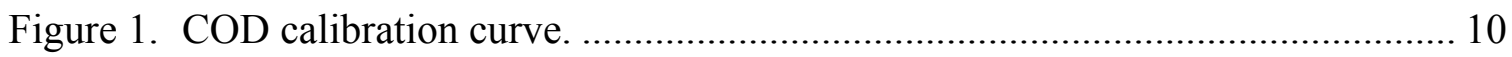

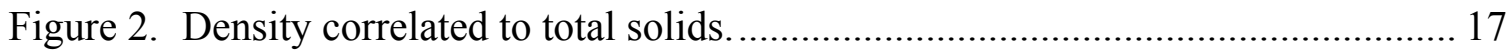

Figure 3. REDOX model with formate, oxalate, coal, nitrate, and manganese normalized

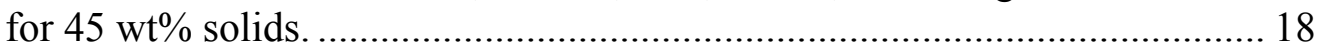

Figure 4. Comparison of the Electron Equivalents to the COD response weighted by the

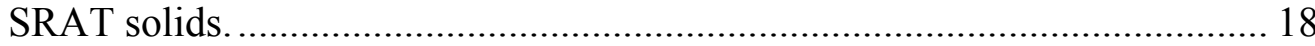

Figure 5. Comparison of the measured REDOX to the COD response weighted by the

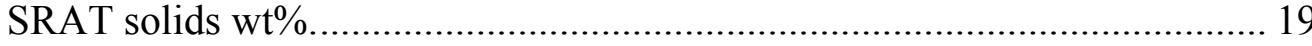


WSRC-TR-2003-00322, Rev. 0

\section{LIST OF ACRONYMS}

\begin{tabular}{|l|l|}
\hline AVE & Average \\
\hline COD & Chemical Oxygen Demand \\
\hline DWPF & Defense Waste Processing Facility \\
\hline EE & Electron Equivalents \\
\hline HLW & High Level Waste \\
\hline LSFM & Large Slurry Fed Melter \\
\hline PNNL & Pacific Northwest National Laboratory \\
\hline PSCM & Pilot Scale Ceramic Melter \\
\hline REDOX & REDuction/OXidation \\
\hline RSD & Relative Standard Deviation \\
\hline SD & Standard Deviation \\
\hline SME & Slurry Mix Evaporator \\
\hline SRAT & Sludge Receipt and Adjustment Tank \\
\hline SRL & Savannah River Laboratory \\
\hline SRS & Savannah River Site \\
\hline SRTC & Savannah River Technology Center \\
\hline WSRC & Westinghouse Savannah River Co. \\
\hline
\end{tabular}


WSRC-TR-2003-00322, Rev. 0

This page intentionally left blank. 


\title{
CHEMICAL OXYGEN DEMAND (COD) FOR MONITORING REDUCTION-OXXIDATION (REDOX) EQUILIBRIUM DURING HIGH LEVEL WASTE (HLW) VITRIFICATION (U)
}

\author{
C. M. Jantzen and M.J. Whitaker \\ Westinghouse Savannah River Company \\ Savannah River Site \\ Aiken, South Carolina 29808
}

\subsection{INTRODUCTION}

\subsection{DWPF PROCESS CONSTRAINTS}

High-level nuclear waste is being immobilized at the Savannah River Site (SRS) by vitrification into borosilicate glass at the Defense Waste Processing Facility (DWPF). In the DWPF Sludge Receipt and Adjustment Tank (SRAT), the insoluble fraction of the waste sludge is refluxed with acid [1] for the following reasons:

- control potential foaming by gaseous species in the melter by:

- converting $\mathrm{NO}_{3}$ (entering as nitrate species in the feed) to $\mathrm{NO}_{2}, \mathrm{NO}$, and/or

$\mathrm{N}_{2}$,

- converting carbonates in the feed to $\mathrm{CO}_{2}$, and

- converting $>66 \%$ of the oxidized $\mathrm{Mn}^{+4}$ or $\mathrm{Mn}^{+3}$ present as $\mathrm{MnO}_{2}, \mathrm{Mn}_{2} \mathrm{O}_{3}$, and $\mathrm{Mn}_{3} \mathrm{O}_{4}$ and/or hydrous complexes in the feed to $\mathrm{MnO}$, liberating $\mathrm{O}_{2}$;

- $\quad$ steam strip mercury for subsequent removal, $\mathrm{HgO} \rightarrow \mathrm{Hg}^{0}$; and

- improve slurry rheology by neutralizing excess hydroxide $\left(\mathrm{OH}^{-}\right)$in the feed.

The SRAT product is then fed to the DWPF Slurry Mix Evaporator (SME), where a borosilicate glass frit slurry is added to produce the melter feed slurry. The melter feed slurry is typically concentrated to $45-50 \mathrm{wt} \%$ total solids in the SME and then fed to the DWPF joule-heated melter where it is fused into glass (vitrified) at $1150^{\circ} \mathrm{C}$.

Prior to 1982, the DWPF reference flowsheet prescribed that $28 \mathrm{wt} \%$ sludge oxides (on a dry calcine basis) from the SRAT be combined with $72 \mathrm{wt} \%$ frit oxides in the SME. Formic acid was the only acid added during SRAT processing. Most glasses produced from this "sludge-only" and "formic acid-only" flowsheet were highly reduced, e.g. $>>0.33 \mathrm{Fe}^{+2} / \Sigma \mathrm{Fe}$. Any carbon containing species in melter feeds (coal, oxalate, formic acid, sugar) cause reduction of transition metal species such as $\mathrm{Fe}^{+3}$ and $\mathrm{Mn}^{+4}$ at the elevated melter temperatures $[2,3,4]$. The interaction of the carbon with the transition metal species in the waste feed occurs primarily in the melter cold cap $[5,6]$. 


\section{WSRC-TR-2003-00322, Rev. 0}

Excess reduction of transition metal species in the melter can cause the following to occur:

- liberation of oxygen which can cause foaming from decomposition of $\mathrm{Mn}^{+4}$ or $\mathrm{Mn}^{+3}$ species if they were not previously reduced during SRAT processing

- reduction of metallic species such as $\mathrm{NiO} \rightarrow \mathrm{Ni}^{\circ}$ and $\mathrm{RuO}_{2} \rightarrow \mathrm{Ru}^{\circ}$ which may fall to the melter floor and cause shorting of electrical pathways in the melt and accumulations which may hinder glass pouring

- reduction of sulfate $\left(\mathrm{SO}_{4}{ }^{=}\right)$to sulfide $\left(\mathrm{S}^{=}\right)$which can complex with $\mathrm{Ni}^{\circ}$ and/or $\mathrm{Fe}^{\circ}$ to form metal sulfides which can fall to the melter floor and cause shorting of electrical pathways and/or hinder glass pouring

- reduced glasses which can be less durable than their oxidized equivalents [7].

Controlling the DWPF melter at a REDuction/OXidation (REDOX) equilibrium of $\mathrm{Fe}^{+2} / \Sigma \mathrm{Fe} \leq 0.33[2,8]$ prevents the potential for conversion of $\mathrm{NiO} \rightarrow \mathrm{Ni}^{\circ}, \mathrm{RuO}_{2} \rightarrow \mathrm{Ru}^{\circ}$, and $2 \mathrm{SO}_{4}{ }^{=} \rightarrow \mathrm{S}_{2}+4 \mathrm{O}_{2}$ during vitrification. Control of foaming due to deoxygenation of manganic species is achieved by having 66-100\% of the $\mathrm{MnO}_{2}$ or $\mathrm{Mn}_{2} \mathrm{O}_{3}$ species converted to $\mathrm{MnO}$ [ 9 ] during SRAT refluxing. At the lower redox limit of $\mathrm{Fe}^{+2} / \Sigma \mathrm{Fe} \sim$ 0.09 about $99 \%$ of the $\mathrm{Mn}^{+3}$ is converted to $\mathrm{Mn}^{+2}$ [2, 8]. Therefore, the lower REDOX limit eliminates melter foaming from deoxygenation.

While nitric acid can be used to control feed rheology and destroy carbonates, only a reducing acid such as formic acid can convert $\mathrm{HgO} \rightarrow \mathrm{Hg}^{0}$ when it is present in a feed and convert $\mathrm{MnO}_{2} \rightarrow \mathrm{MnO}+1 / 2 \mathrm{O}_{2}$ in the SRAT. The REDOX equilibrium in DWPF is controlled by balancing organic reductants (formic acid, coal, soluble oxalates and insoluble oxalates) and oxidizers (nitric acid, sodium nitrate, sodium nitrite, and $\mathrm{MnO}_{2}$ ) additions to the SRAT.

Chemical reduction is defined as making an atom or molecule less positive by electron transfer, while oxidation is defined as making an atom or molecule more positive by electron transfer. Therefore, the number of electrons transferred for each REDuction/OXidation reaction can be summed and an Electron Equivalents term for each organic and oxidant species defined. $*$ The formalism developed [10] for DWPF REDOX control from feed composition is represented by the number of electrons gained during reduction of an oxidant or lost during oxidation of a reductant. The overall relationship between the REDOX ratio and the feed is given in term of the transfer of molar Electron Equivalents, $\xi$ :

* Because the water content of a melter feed alters the species concentrations of the [reductants] and [oxidants], it can influence the equilibrium oxygen fugacity $\left(f_{\mathrm{O}_{2}}\right)$ in a melter during vitrification.

Since the effects of water on oxygen fugacity are small relative to the impact of dilution on feed concentrations, the molar concentrations of the reductants and oxidants must be adjusted to a constant $\mathrm{wt} \%$ solids basis. A value of $45 \mathrm{wt} \%$ solids was chosen as the nominal $\mathrm{wt} \%$ solids for most DWPF melter feeds in the Electron Equivalents model shown in Equation 1. 
WSRC-TR-2003-00322, Rev. 0

Equation $1 \quad \frac{F e^{2+}}{\Sigma F e}=f\left[\left(2[F]+4[C]+4\left[\mathrm{O}_{\mathrm{T}}\right]-5[N]-2[M n]\right) \frac{45}{T}\right]=f[\xi]$

where $f=$ indicates a function

$[\mathrm{F}]=$ formate $(\mathrm{mol} / \mathrm{kg}$ feed $)$

$[\mathrm{C}]=\operatorname{coal}$ (carbon) $(\mathrm{mol} / \mathrm{kg}$ feed $)$

$\left[\mathrm{O}_{\mathrm{T}}\right]=$ oxalate $_{\text {Total }}($ soluble and insoluble $)(\mathrm{mol} / \mathrm{kg}$ feed $)$

$[\mathrm{N}]=$ nitrate + nitrite $(\mathrm{mol} / \mathrm{kg}$ feed $)$

$[\mathrm{Mn}]=$ manganese $_{\text {Total }}($ soluble and insoluble $)(\mathrm{mol} / \mathrm{kg}$ feed $)$

$\mathrm{T}=$ total solids $(\mathrm{wt} \%)$

and $\xi(\mathrm{mol} / \mathrm{kg}$ feed at $45 \mathrm{wt} \%$ solids $)=\left(2[F]+4[C]+4\left[\mathrm{O}_{\mathrm{T}}\right]-5[N]-2[\mathrm{Mn}]\right) \frac{45}{T}$

\subsection{PURPOSE OF THE CURRENT STUDY}

In order to implement the Electron Equivalents REDOX model in DWPF, nine * analyses are needed on the DWPF feed (formate, nitrate, nitrite, soluble oxalate, insoluble oxalate, coal, soluble $\mathrm{Mn}^{+2}$, insoluble $\mathrm{Mn}^{+4}$, and $\mathrm{wt} \%$ solids). The current study addresses a simple and rapid analysis method that would substitute one measurement, chemical oxygen demand (COD) for four of the analyses (formate, soluble oxalate, insoluble oxalate, and coal). In addition, COD analyses may monitor the relative role of both the reductants and the oxidants which would result in even fewer complex analyses to perform. This would significantly improve melter feed acceptability turn around time. In addition, the method for coal is difficult and time consuming, involving sieving and isolation of the coal from the remainder of the sludge by wet sieving [11]. Substitution of a simpler method to measure the sum of the organic reductants and/or the oxidants would improve the overall feed acceptability turn around time without compromising REDOX control in DWPF.

\subsection{BACKGROUND}

\subsection{REDOX PROCESS LIMITS}

The DWPF melt and glass REDOX equilibria have been well studied. Based on the work of Schreiber[2] and Goldman[3], Jantzen and Plodinec [8] originally defined acceptable REDOX ratios (based on the measured $\mathrm{Fe}^{2+} / \Sigma \mathrm{Fe}$ ratio) for any DWPF-type melt to be greater than or equal to 0.09 (to prevent foaming via the deoxygenation of $\mathrm{MnO}_{2}, \mathrm{Mn}_{2} \mathrm{O}_{3}$, and $\mathrm{Mn}_{3} \mathrm{O}_{4}$ to $\mathrm{MnO}$ ) and less than or equal to 0.33 (to prevent metallic nickel and nickel sulfide formation). Formate and nitrate concentrations in the melter feed appear to be the

\footnotetext{
* seven analyses if total oxalate (soluble and insoluble) and total manganese (soluble and insoluble) can be measured together
} 
major parameters influencing melt REDOX during vitrification. The formate is a reductant while the nitrate is an oxidant. Since the melt REDOX ratio cannot be directly measured during processing, ${ }^{\dagger}$ the melt REDOX ratio has been related to feed reductant (formate) and oxidizer (nitrate) concentrations (which can be measured). Thus the proper balance between reductants and oxidizers ensures production of a high quality glass, free of metal sulfide precipitation, without impacting production rate (e.g., from foaming), melter life (e.g., from metal formation), or glass performance (e.g. from degradation of durability).

\subsection{REDOX MODELING}

Initially a REDOX model with 1:1 stoichiometry of a single reductant (formic acid) and a single oxidant (nitric acid) was developed known as the $\{[\mathrm{F}]-[\mathrm{N}]\}$ model $[12,13,14,15]$. In 1997, the data used to develop the $\{[\mathrm{F}]-[\mathrm{N}]\}$ relationship was revisited and glass quality and REDOX measurement criteria were developed to screen the experimental data used for modeling [16]. This redefined the population of glasses being modeled by excluding those below the $\mathrm{Fe}^{+2} / \Sigma \mathrm{Fe}$ measurement detection limit of 0.03 and those that precipitated metallic and/or sulfide species. Regression of the redefined data demonstrated that the $\{[\mathrm{F}]-[\mathrm{N}]\}$ parameter was a less accurate predictor $\left(\mathrm{R}^{2}=0.68\right)$ of waste glass REDOX than had previously been calculated $\left(\mathrm{R}^{2}=0.80\right)$. In addition, there was no known mechanistic impetus for using the molar difference of the reductants and oxidants for REDOX prediction. This artificially set the relative oxidation/reduction potentials of nitrate and formate to be equivalent when it was well known that nitric acid is a strong oxidizer and formic acid is a weak reductant.

The regression of the redefined data showed that there was an $\{[\mathrm{F}]-3[\mathrm{~N}]\}$ relationship between the feed reductants and oxidants and the REDOX ratio of the glass yielding an $\mathrm{R}^{2}=0.88$. The $\{[\mathrm{F}]-3[\mathrm{~N}]\}$ model, based solely on the molar formate and nitrate concentrations in the DWPF feeds, was implemented in DWPF in January 2000 while processing Sludge Batch 1B (SB1B, SRAT Batch 134). The $\{[\mathrm{F}]-3[\mathrm{~N}]\}$ REDOX model has been used since then to control REDOX at a target $\mathrm{Fe}^{2+} / \Sigma \mathrm{Fe} \sim 0.2$ in an effort to improve melt rate by reducing the foaming caused by the excess nitric acid being added.

Both the $\{[\mathrm{F}]-[\mathrm{N}]\}$ and the $\{[\mathrm{F}]-3[\mathrm{~N}]\}$ REDOX models assumed that the melter feeds were properly formated and refluxed to ensure that $66-100 \%$ of the $\mathrm{Mn}^{3+}$ and $\mathrm{Mn}^{4+}$ were converted to $\mathrm{Mn}^{+2}$ as $\mathrm{Mn}(\mathrm{COOH})_{2}$. They were each based on only one reductant (formate) and one oxidant (nitrate) even though other organics such as phenol were present and manganic species were present. The recently developed Electron Equivalents REDOX model [10] makes no assumption about the oxidation state of the manganese or about the total destruction of the nitrite during SRAT processing. In addition, the Electron Equivalents REDOX model accounts for additional reductants such as oxalate and coal (see Equation 1) and the expanded version of this model also accounts for the

$\dagger$ Originally the REDOX for a vitrified melter feed sample was to be measured to determine feed acceptability; however, the expense and time necessary for these measurements provided impetus to relate melt REDOX to feed chemistry. 
use of solid reductants such as sugar. The Electron Equivalents REDOX model has an $\mathrm{R}^{2}$ $=0.80[10]$.

\subsection{CHEMICAL OXYGEN DEMAND (COD) MEASURMENTS}

Chemical Oxygen Demand (COD) is a titrametric technique that analyzes the reducing strength of melter feeds. The COD technique for glass was developed by the FMC Corporation [17]. It is a minor variation of the ASTM Standard Method for Chemical Oxygen Demand of Industrial Waste Water which measures the oxidizable organic matter content in water [18]. The COD method uses a strong chemical oxidant in acid solution and heat to oxidize organic carbon to $\mathrm{CO}_{2}$ and $\mathrm{H}_{2} \mathrm{O}$. By definition, chemical oxygen demand is "a measure of the oxygen equivalent of the organic matter content of a sample that is susceptible to oxidation by a strong chemical oxidant [18]."

For application to melter feeds, a known mass of melter feed is refluxed for several hours with sulfuric acid and potassium dichromate. Any oxidizable component in the feed will be oxidized under these conditions. The only reactions which should occur with the melter feeds are those of the dichromate with organics and any reduced species such as $\mathrm{Mn}^{+2}$ in the feed via reactions such as the following:

Equation $2 \mathrm{Cr}_{2} \mathrm{O}_{7}^{-2}+8 \mathrm{H}^{+}+3 \mathrm{HCOOH} \rightarrow 2 \mathrm{Cr}^{+3}+7 \mathrm{H}_{2} \mathrm{O}+3 \mathrm{CO}_{2}$

Equation $3 \mathrm{Cr}_{2} \mathrm{O}_{7}^{-2}+2 \mathrm{H}^{+}+3 \mathrm{Mn}^{+2} \rightarrow 2 \mathrm{Cr}^{+3}+\mathrm{H}_{2} \mathrm{O}+3 \mathrm{MnO}_{2}$

The rest of the components in the feed, including all of the oxides in the frit, are already in their highest oxidation state. If there is no $\mathrm{Mn}^{+2}$ in the feed, only the organic contribution will be measured by COD analysis.

The dichromate is added in excess, and this excess is titrated with $\mathrm{Fe}^{+2}$. Since the amount of dichromate initially added is known, as is the amount left after reflux, the amount consumed by the feed is found by difference. The results are expressed as weight percent carbon equivalent, i.e. the amount of carbon that would be consumed by that amount of dichromate:

Equation $4 \mathrm{Cr}_{2} \mathrm{O}_{7}^{-2}+3 \mathrm{C}+2 \mathrm{H}^{+} \rightarrow 2 \mathrm{Cr}^{+3}+\mathrm{H}_{2} \mathrm{O}+3 \mathrm{CO}_{2}$

The COD measurement technique was explored at SRTC (then known as the Savannah River Laboratory, SRL) in 1982 by P.D. Soper [17]. At that time a formic acid only and sludge only flowsheet were being developed for the DWPF. The precision of the COD measurement technique was found to be excellent. In additional, the measured COD response was determined to be a linear function of the REDOX ratio expressed as $\mathrm{Fe}^{+2} / \mathrm{Fe}^{+3}$. Both crucible and pilot scale melter feeds from SRL (Large Slurry Fed Melter, LSFM) and Pacific Northwest Laboratory (PNL Small Cylindrical Melter, PSCM) were tested. It was noted that the COD vs. $\mathrm{Fe}^{+2} / \mathrm{Fe}^{+3}$ relationship was melter specific due to 


\section{WSRC-TR-2003-00322, Rev. 0}

larger air in-leakage of the SRL LSFM versus the PSCM, but that the COD method could be useful to control the reducing capacity of the feed independent of melter air inleakage.

This method calculates the carbon equivalents in grams per mole of reductant and adjusts them for their relative reducing power. For example in one mole of formate there is only one mole of carbon which has an atomic weight of 12 but a valence of +2 . In one mole of coal there is also one mole of carbon, it has an atomic weight of 12 , and a valence of 0 . Due to the difference in the oxidation states of the carbon in coal and formic acid, a mole of carbon in formic acid transfers 2 electrons when it oxidizes to $\mathrm{C}^{+4} \mathrm{O}_{2}$ while the coal transfers 4 electrons when it oxidizes to $\mathrm{C}^{+4} \mathrm{O}_{2}$. Therefore, one mole of carbon in formic acid is considered as 6 grams of carbon equivalents per mole on COD analysis while one mole of carbon in coal is considered as 12 grams of carbon equivalents per mole [17]. Moreover, Soper [17] had normalized the carbon equivalents by the $\mathrm{wt} \%$ feed solids in order to be able to model both dilute and concentrated feeds. Therefore, Soper [17] expressed the COD relationship to $\mathrm{Fe}^{+2} / \mathrm{Fe}^{+3}$ in terms of $\mathrm{wt} \% \mathrm{C} /$ feed solids.

Investigation of the COD methodology to measure REDOX of feeds in DWPF was abandoned in 1986 when high nitrate compounds such as sodium nitrate (a corrosion inhibitor)[19], hydroxylamine nitrate (to reduce nitrite to nitrous oxide), and nitric acid (substitution of nitric acid for a portion of the formic acid) [20] were introduced into various flowsheet options. It was assumed that the presence of excessive nitrate, a melt oxidizer, would interfere with the COD measurement.

\subsection{EXPERIMENTAL}

\subsection{FEED PREPARATION AND ANALYSES}

Detailed preparation and analyses of the SME feeds used in the COD measurements and the crucible studies are given elsewhere [10]. The feeds varied in formic, nitrate, nitrite, oxalate, coal, and manganese content over the concentrations anticipated for SB3. The feeds all contained between $10 \mathrm{wt} \%$ to $100 \mathrm{wt} \%$ of the amount of noble metals calculated to be present in Tank 7. Manganese in the air-dried simulated sludges was $2.92 \mathrm{wt} \%$ on a dry solids basis $\left(110-115^{\circ} \mathrm{C}\right)$ for the Tank 8 simulants* and $3.87 \mathrm{wt} \%$ on a dry solids basis $\left(110-115^{\circ} \mathrm{C}\right)$ in the Tank 7 simulant.

Coal size, type and treatment were varied as shown in Table 1. Coal treatment included irradiation and caustic treatment of filter specification size coal (coarse) and fine coal to simulate degradation after years of tank storage. The filter specification size coal was

\footnotetext{
A Tank 8 simulant was used until a SB3 Tank 7 simulant was available. The elemental composition of both was similar and the anion content of the Tank 8 simulant was adjusted to match the anticipated composition of Tank 7.
} 


\section{WSRC-TR-2003-00322, Rev. 0}

provided by the manufacturer of the K-Area filters and ranged between 0.6 to $0.8 \mathrm{~mm}$. The fine coal was $\sim 0.21 \mathrm{~mm}$ in diameter. ${ }^{\dagger}$

Table 1 summarizes the measured REDOX and waste loading data for the 53 glasses used in the development of the Electron Equivalents model. Table 1 also gives the SME concentrations on which COD was measured.

$\dagger \quad$ J.R. Fowler, "Particle Distribution of Coal and Sand in Tank 7," Interoffice Memorandum, September 20, 1979. 
WSRC-TR-2003-00322, Rev. 0

Table 1 Adjusted SME Concentrations, Chemical Oxygen Demand, REDOX, and Calculated Electron Equivalents

\begin{tabular}{|c|c|c|c|c|c|c|c|c|c|c|c|c|}
\hline Sample ID & $\begin{array}{c}\text { COD } \\
(\mathrm{mol} / \mathrm{kg})\end{array}$ & $\begin{array}{c}\text { COD } \\
\text { (mol/kg) } \\
\text { * SRAT } \\
\text { Wt\% } \\
\text { Solids } \\
\end{array}$ & Coal Type and Size & $\begin{array}{c}\text { Target } \\
\text { Waste } \\
\text { Loading } \\
\text { (wt\%) }\end{array}$ & $\begin{array}{l}\text { REDOX } \\
\mathrm{Fe}^{+2} / \Sigma \mathrm{Fe}\end{array}$ & $\begin{array}{c}\text { Adjusted } \\
\text { SME } \\
\text { Total } \\
\text { Solids } \\
\text { (wt\%) } \\
\end{array}$ & $\begin{array}{c}\text { Adjusted } \\
\text { Oxalate } \\
\text { (mol/kg) }\end{array}$ & $\begin{array}{c}\text { Adjusted } \\
\text { Formate } \\
\text { (mol/kg) }\end{array}$ & $\begin{array}{c}\text { Adjusted } \\
\text { Nitrate } \\
\text { (mol/kg) }\end{array}$ & $\begin{array}{c}\text { Adjusted } \\
\text { Coal } \\
\text { (mol/kg) }\end{array}$ & $\begin{array}{c}\text { Adjusted } \\
\text { Mn } \\
\text { (mol/kg) }\end{array}$ & $\begin{array}{c}\text { Electron } \\
\text { Equivalents } \\
\text { (mol/kg } \\
\text { feed @ } 45 \\
\text { wt } \% \text { solids) }\end{array}$ \\
\hline SB3-1-25-320 & 0.21 & 5.52 & None & 25 & 0.119 & 42.80 & 0.000 & 0.321 & 0.154 & 0.000 & 0.065 & -0.271 \\
\hline SB3-1-30-320 & 0.22 & 5.32 & None & 30 & 0.074 & 40.47 & 0.000 & 0.322 & 0.154 & 0.000 & 0.098 & -0.360 \\
\hline SB3-5-30-320 & 0.27 & 8.83 & None & 30 & 0.407 & 43.24 & 0.270 & 0.385 & 0.187 & 0.000 & 0.064 & 0.820 \\
\hline SB3-5-35-320 & 0.35 & 11.06 & None & 35 & 0.451 & 41.06 & 0.298 & 0.401 & 0.195 & 0.000 & 0.074 & 0.956 \\
\hline SB3-6-25-320 & 0.23 & 7.44 & None & 25 & 0.370 & 46.66 & 0.128 & 0.360 & 0.139 & 0.000 & 0.061 & 0.400 \\
\hline SB3-6-30-320 & 0.29 & 8.68 & None & 30 & 0.267 & 42.01 & 0.155 & 0.375 & 0.145 & 0.000 & 0.076 & 0.527 \\
\hline SB3-7-25-320 & 0.23 & 6.17 & None & 25 & 0.125 & 42.01 & 0.237 & 0.304 & 0.265 & 0.000 & 0.049 & 0.141 \\
\hline SB3-7-30-320 & 0.29 & 7.34 & None & 30 & 0.193 & 37.75 & 0.284 & 0.315 & 0.275 & 0.000 & 0.063 & 0.317 \\
\hline SB3-7-35-320 & 0.31 & 7.57 & None & 35 & 0.142 & 36.02 & 0.318 & 0.325 & 0.283 & 0.000 & 0.073 & 0.446 \\
\hline SB3-15-30-320 & 0.38 & 9.97 & $\begin{array}{c}\text { Fine, Caustic } \\
\text { Treated, Irradiated }\end{array}$ & 30 & 0.331 & 39.04 & 0.197 & 0.573 & 0.248 & 0.006 & 0.057 & 0.702 \\
\hline SB3-1-25-202 & 0.24 & 6.43 & None & 25 & 0.105 & 42.84 & 0.000 & 0.321 & 0.154 & 0.000 & 0.065 & -0.271 \\
\hline SB3-1-35-202 & 0.26 & 6.03 & None & 35 & 0.118 & 35.50 & 0.000 & 0.362 & 0.174 & 0.000 & 0.074 & -0.369 \\
\hline SB3-2-25-200 & 0.23 & 6.10 & Act Carb & 25 & 0.242 & 42.99 & 0.000 & 0.307 & 0.159 & 0.078 & 0.061 & 0.006 \\
\hline SB3-2-30-200 & 0.23 & 5.64 & Act Carb & 30 & 0.212 & 37.27 & 0.000 & 0.325 & 0.169 & 0.089 & 0.070 & 0.027 \\
\hline SB3-2-35-200 & 0.25 & 6.02 & Act Carb & 35 & 0.136 & 33.67 & 0.000 & 0.345 & 0.179 & 0.090 & 0.071 & 0.017 \\
\hline SB3-3-25-200 & 0.27 & 7.59 & Act Carb & 25 & 0.275 & 43.85 & 0.000 & 0.399 & 0.162 & 0.078 & 0.059 & 0.189 \\
\hline SB3-4-25-202 & 0.23 & 6.17 & Act Carb & 25 & 0.138 & 43.24 & 0.000 & 0.302 & 0.164 & 0.079 & 0.063 & -0.027 \\
\hline SB3-6-25-202 & 0.28 & 8.74 & None & 25 & 0.336 & 46.67 & 0.128 & 0.359 & 0.139 & 0.000 & 0.061 & 0.400 \\
\hline SB3-6-30-202 & 0.28 & 8.35 & None & 30 & 0.288 & 42.66 & 0.161 & 0.371 & 0.144 & 0.000 & 0.080 & 0.536 \\
\hline SB3-7-25-202 & 0.28 & 7.49 & None & 25 & 0.193 & 42.24 & 0.281 & 0.291 & 0.254 & 0.000 & 0.065 & 0.327 \\
\hline SB3-7-30-202 & 0.34 & 8.65 & None & 30 & 0.141 & 38.15 & 0.253 & 0.324 & 0.283 & 0.000 & 0.052 & 0.166 \\
\hline SB3-7-35-202 & 0.27 & 6.54 & None & 35 & 0.155 & 35.40 & 0.307 & 0.328 & 0.286 & 0.000 & 0.070 & 0.400 \\
\hline SB3-8-25-202 & 0.28 & 7.51 & Act Carb & 25 & 0.272 & 41.79 & 0.234 & 0.299 & 0.266 & 0.059 & 0.048 & 0.373 \\
\hline SB3-8-35-202 & 0.32 & 7.77 & Act Carb & 35 & 0.175 & 34.91 & 0.262 & 0.334 & 0.297 & 0.066 & 0.053 & 0.500 \\
\hline
\end{tabular}


WSRC-TR-2003-00322, Rev. 0

\begin{tabular}{|c|c|c|c|c|c|c|c|c|c|c|c|c|}
\hline Sample ID & $\begin{array}{c}\text { COD } \\
(\mathrm{mol} / \mathrm{kg})\end{array}$ & $\begin{array}{c}\begin{array}{c}\text { COD } \\
\text { (mol/kg) }\end{array} \\
\text { * SRAT } \\
\text { Wt } \% \\
\text { Solids }\end{array}$ & Coal Type and Size & $\begin{array}{c}\text { Target } \\
\text { Waste } \\
\text { Loading } \\
\text { (wt\%) }\end{array}$ & $\begin{array}{l}\text { REDOX } \\
\mathrm{Fe}^{+2} / \Sigma \mathrm{Fe}\end{array}$ & $\begin{array}{c}\text { Adjusted } \\
\text { SME } \\
\text { Total } \\
\text { Solids } \\
\text { (wt\%) } \\
\end{array}$ & $\begin{array}{c}\text { Adjusted } \\
\text { Oxalate } \\
\text { (mol/kg) }\end{array}$ & $\begin{array}{l}\text { Adjusted } \\
\text { Formate } \\
\text { (mol/kg) }\end{array}$ & $\begin{array}{c}\text { Adjusted } \\
\text { Nitrate } \\
\text { (mol/kg) }\end{array}$ & $\begin{array}{c}\text { Adjusted } \\
\text { Coal } \\
\text { (mol/kg) }\end{array}$ & $\begin{array}{c}\text { Adjusted } \\
\text { Mn } \\
\text { (mol/kg) }\end{array}$ & $\begin{array}{c}\text { Electron } \\
\text { Equivalents } \\
\text { (mol/kg } \\
\text { feed @ } 45 \\
\text { wt\% solids) }\end{array}$ \\
\hline SB3-9-25-202 & 0.32 & 8.90 & Spec Size & 25 & 0.243 & 42.89 & 0.227 & 0.327 & 0.219 & 0.059 & 0.051 & 0.631 \\
\hline SB3-9-30-202 & 0.40 & 10.43 & Spec Size & 30 & 0.225 & 39.02 & 0.243 & 0.349 & 0.234 & 0.063 & 0.055 & 0.740 \\
\hline SB3-10-35-202 & 0.41 & 10.07 & Spec Size & 35 & 0.342 & 35.71 & 0.208 & 0.412 & 0.227 & 0.007 & 0.056 & 0.549 \\
\hline SB3-11-25-202 & 0.37 & 10.39 & Spec Size & 25 & 0.387 & 42.79 & 0.180 & 0.409 & 0.189 & 0.006 & 0.051 & 0.539 \\
\hline SB3-12-25-202 & 0.27 & 7.59 & $\begin{array}{l}\text { Spec Size, Caustic } \\
\text { Treated, Irradiated }\end{array}$ & 25 & 0.334 & 43.03 & 0.186 & 0.424 & 0.237 & 0.059 & 0.051 & 0.562 \\
\hline SB3-12-30-202 & 0.41 & 11.04 & $\begin{array}{l}\text { Spec Size, Caustic } \\
\text { Treated, Irradiated }\end{array}$ & 30 & 0.346 & 39.21 & 0.198 & 0.452 & 0.253 & 0.063 & 0.055 & 0.658 \\
\hline SB3-13-25-202 & 0.30 & 8.72 & Fine & 25 & 0.342 & 43.15 & 0.202 & 0.486 & 0.254 & 0.059 & 0.053 & 0.670 \\
\hline SB3-13-30-202 & 0.36 & 9.57 & Fine & 30 & 0.352 & 39.31 & 0.215 & 0.519 & 0.271 & 0.063 & 0.057 & 0.785 \\
\hline SB3-14-30-202 & 0.42 & 11.07 & Fine & 30 & 0.371 & 39.01 & 0.219 & 0.440 & 0.236 & 0.007 & 0.056 & 0.568 \\
\hline SB3-15-25-202 & 0.27 & 7.77 & $\begin{array}{c}\text { Fine, Caustic } \\
\text { Treated, Irradiated }\end{array}$ & 25 & 0.382 & 42.87 & 0.185 & 0.537 & 0.232 & 0.006 & 0.053 & 0.600 \\
\hline SB3-15-30-202 & 0.34 & 9.13 & $\begin{array}{c}\text { Fine, Caustic } \\
\text { Treated, Irradiated }\end{array}$ & 30 & 0.360 & 39.04 & 0.197 & 0.573 & 0.248 & 0.006 & 0.057 & 0.703 \\
\hline SB3-16-25-202 & 0.27 & 7.42 & $\begin{array}{c}\text { Fine, Caustic } \\
\text { Treated, Irradiated }\end{array}$ & 25 & 0.321 & 42.52 & 0.212 & 0.412 & 0.249 & 0.059 & 0.052 & 0.588 \\
\hline SB3-18-25-202 & 0.21 & 5.73 & $\begin{array}{c}\text { Fine, Caustic } \\
\text { Treated, Irradiated }\end{array}$ & 25 & 0.044 & 43.32 & 0.000 & 0.414 & 0.221 & 0.078 & 0.066 & -0.104 \\
\hline
\end{tabular}




\subsection{COD ANALYSES}

\subsubsection{Standard COD Analyses}

Over 200 simulated SB3 SME products, each representative of a glass sample made during the development of the Electron Equivalents REDOX model, were reacted with an acidic solution of potassium dichromate in the presence of a catalyst (silver) and digested at a temperature of $150^{\circ} \mathrm{C}$. The COD reagent also contains mercury that complexes chloride interference since chloride was present in the simulated SME products. Oxidizable organic compounds reduce the yellow colored dichromate ion $\left(\mathrm{Cr}_{2} \mathrm{O}_{7}{ }^{2-}\right)$ to the green colored chromic ion $\left(\mathrm{Cr}^{3+}\right)$. The amount of chromic ion produced is measured colorimetrically. The results are expressed as the number of milligrams of oxygen $\left(\mathrm{O}_{2}\right)$ consumed per liter of sample $(\mathrm{mg} / \mathrm{L} \mathrm{COD})$. This number can be converted to carbon equivalents on a molar basis since one mole of $\mathrm{O}_{2}$ and one mole of $\mathrm{C}$ are needed to form $\mathrm{CO}_{2}$.

Initially a series of standards were analyzed ranging from $0 \mu \mathrm{g} / \mathrm{mL}$ to $10,000 \mu \mathrm{g} / \mathrm{mL}$ in order to determine linearity and the dynamic range of the COD method. The standards were prepared from a stock $10,000 \mu \mathrm{g} / \mathrm{mL}$ COD standard purchased from Chemetrics. A graph and data results are in Figure 1 and Table 2. The method is very linear in this dynamic range with a correlation factor of 0.99997.

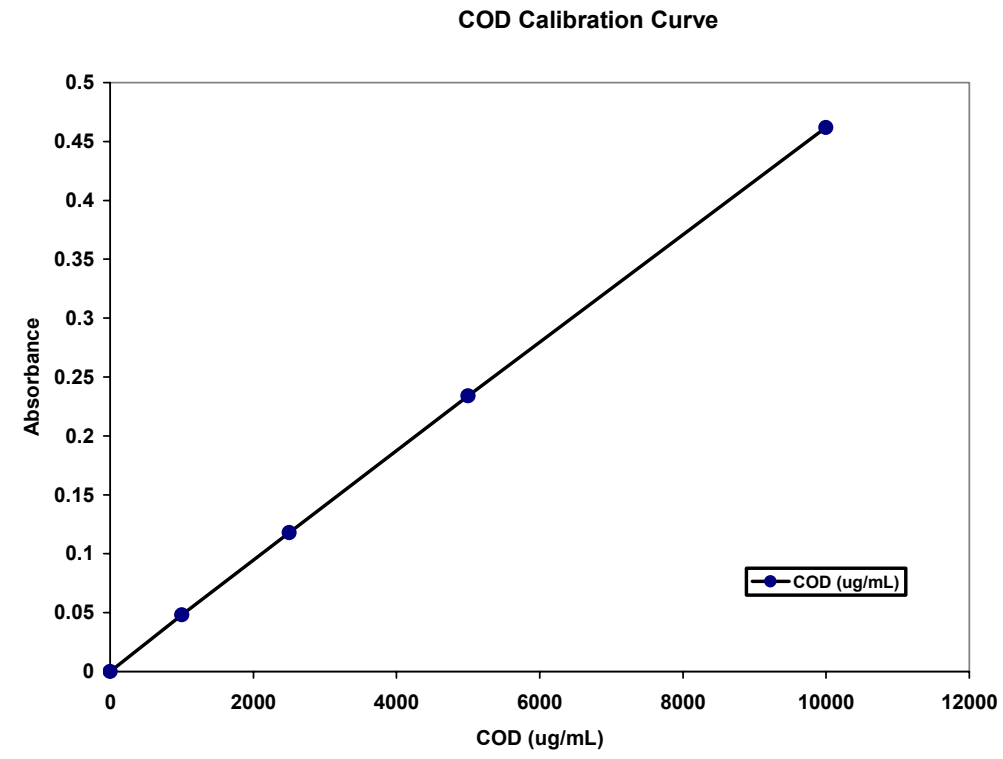

Figure 1. COD calibration curve. 
WSRC-TR-2003-00322, Rev. 0

Table 2 COD Calibration Curve Data

\begin{tabular}{cc} 
Standard & Absorbance \\
\hline 10000 & 0.462 \\
5000 & 0.234 \\
2500 & 0.118 \\
1000 & 0.048 \\
0 & 0
\end{tabular}

To further evaluate the COD technique and before beginning SB3 SME simulant analyses, a few initial experiments were done to determine the precision and effectiveness of the method on a few selected SB3 simulant samples. Two sets of SB3 simulant samples were analyzed in triplicate by the procedure recommended by the manufacturer. The manufacturer's protocol for this procedure is to pipette a specific known volume of sample into the reagent vial. The vial is capped and mixed thoroughly and then placed in the digestion device. The sample is digested at $150^{\circ} \mathrm{C}$ for two hours, then removed to allow to cool for one hour before measuring the concentration of COD. The results of the two sets of SB3 SME simulant samples are in Table 3.

Table 3 Reproducibility of SME COD Analyses

\begin{tabular}{lllll} 
Samples & Conc. & AVE & SD & RSD \\
\hline & & & & \\
SB3-3-1 & 17,611 & & & \\
SB3-3-2 & 19,037 & & & \\
SB3-3-3 & 18,418 & & & \\
& & & & \\
& & & & \\
SB3-1-25-202-1 & 10,619 & & & \\
SB3-1-25-202-2 & 11,269 & 10,958 & 326 & 2.97
\end{tabular}

Based on these results with relative standard deviations $<5 \%$ it was decided to proceed with the analyses of the COD/SB3 SME simulants. All 200 SB3 simulant samples prepared were analyzed one time using the procedure recommended by the manufacturer.

Considering that some of these simulant samples contain particles of coal, it was felt that it would be useful to know the effectiveness of oxidation of the particles by the COD technique outside the simulant matrix. The particles were analyzed using the procedure recommended by the manufacturer. One to ten particles were added to the reagent vials 


\section{WSRC-TR-2003-00322, Rev. 0}

and allowed to digest for two hour at $150^{\circ} \mathrm{C}$. It should be noted that in each case the coal was not totally consumed by the reagent and particles of coal remained in the vials after the two hour digestion. However, as one might expect, as the number of coal particles increased so did the COD concentration. The relative sizes and surface area of the coal particles was not measured as the goal of these scoping experiments was simply to see if more coal gave an increased COD response. The results are given in Table 4.

Table 4 Increase in COD Response with Coal Concentration

\begin{tabular}{ll} 
Sample & Conc. \\
\hline Coal 1 particle & 1010 \\
Coal 3 particles & 3370 \\
Coal 5 particles & 4310 \\
Coal 10 particles & 7400
\end{tabular}

Upon completion of the COD analyses of the supplied SB3 SME simulant sample series, the results were reviewed. There seemed to be more scatter in the data than was expected. It was decided to investigate the COD methodology more closely and determine if the technique could be modified to improve the precision and not complicate the procedure in the event it may eventually be used in DWPF.

\subsubsection{Modified COD Analyses to Accommodate Coal Digestion}

After evaluation of the COD method and a series of experiments, two minor modifications were made in the procedure to better accommodate SB3 SME simulant oxalate/coal containing samples and improve the precision.

The two modifications made in the procedure were to:

1) remove $\sim 1 / 4$ inch of the pipet tip to ensure representative sampling of the high $\mathrm{wt} \%$ solids SME products, e.g. open the sampling orifice and

2) lengthen the digestion time from two hours to four hours to enhance the digestion of organic material within the sample.

Table 5 demonstrates the effects of sample digestion time at two, four and six hours on COD response. Based on this data a four hour digestion appears to be the optimum length of time for the coal containing SB3 simulant samples. 
WSRC-TR-2003-00322, Rev. 0

Table 5 Results of Various Digestion Times on COD Response

$\underline{\text { Sample ID }}$

SB3-6(2)-25-202 (.0615 Coal)

SB3-6(4)-25-202 (.0615 Coal)

SB3-6(6)-25-202 (.0615 Coal)

SB3-7(2)-25-202 (.0615 Coal)

SB3-7(4)-25-202 (.0615 Coal)

SB3-7(4)-25-202 (.0615 Coal)
Conc (ug/mL)

10,333

11,432

11,156

8,685

9,870

9,610
Digested (hours)

2

4

6

2

4

6

To validate the precision of the modified COD procedure a set of three coal containing SB3 simulant samples were analyzed in triplicate. The results are shown in the table below. The precision is good with relative standard deviations of $<2.5 \%$ for all three samples. It should be noted before digestion the vials are cloudy (murky looking). After digestion the vials were clear and the only particles that seemed to be remaining were attributed to a small amount of frit at the bottom of the vial.

Table 6 Precision of Modified COD Method to Accommodate Coal Digestion

\begin{tabular}{|c|c|c|c|c|}
\hline Sample & OD $(\mathrm{mg} / \mathrm{L})$ & AVE & SD & RSD \\
\hline SB3-5(1)-35-202 (.041 Coal) & 19,867 & & & \\
\hline SB3-5(2)-35-202 (.041 Coal) & 19,362 & & & \\
\hline SB3-5(3)-35-202 (.041 Coal) & 19,174 & 19,468 & 358 & 1.84 \\
\hline SB3-6(1)-35-202 (.041 Coal) & 12,202 & & & \\
\hline SB3-6(2)-35-202 (.041 Coal) & 12,746 & & & \\
\hline SB3-6(3)-35-202 (.041 Coal) & 12,289 & 12,412 & 292 & 2.35 \\
\hline SB3-7(1)-35-202 (.041 Coal) & 11,958 & & & \\
\hline SB3-7(2)-35-202 (.041 Coal) & 11,472 & & & \\
\hline SB3-7(3)-35-202 (.041 Coal) & 11,473 & 11,634 & 280 & 2.41 \\
\hline
\end{tabular}


WSRC-TR-2003-00322, Rev. 0

\subsubsection{Effects of Nitric Acid on COD Analyses}

The presence of nitric acid in the SME samples and its affect on the COD technique was of concern. A few experiments were performed to investigate this issue. Two solutions of sodium oxalate were prepared, one solution without nitric acid and the other in $0.28 \mathrm{M}$ nitric acid. Both solutions were analyzed for COD twelve times. As shown in the table below, samples prepared in $0.28 \mathrm{M}$ nitric acid gave a 3.30\% higher COD value than those samples prepared without nitric acid and the precision for both solution remained at $<2.5 \%$ RSD.

\subsection{QUALITY ASSURANCE}

All the data reported in this study were developed under the quality assurance given in technical task plan WSRC-RP-2002-00341 [21]. The research program and task plan were developed to address TTR - HLW/DWPF/TTR-02-0017. The data are recorded in notebooks WSRC-NB-2002-00156, WSRC-NB-2002-00199, WSRC-NB-2003-00034, and WSRC-NB-99-00100. 
WSRC-TR-2003-00322, Rev. 0

Table $7 \mathrm{HNO}_{3}$ Effects on COD Analyses

\begin{tabular}{lllll} 
Sample ID & Conc. & Average & SD. & RSD \\
\hline SO-13 & 1960 & & \\
SO-14 & 2040 & & \\
SO-15 & 1920 & & \\
SO-16 & 1960 & & \\
SO-17 & 1960 & & \\
SO-18 & 2040 & 1,990 & 38 & \\
SO-19 & 2000 & & \\
SO-20 & 2000 & & \\
SO-21 & 2040 & & \\
SO-22 & 1980 & & \\
SO-23 & 2000 & & \\
SO-24 & 1980 & & \\
& & & \\
SO/NA-13 & 1980 & & \\
SO/NA-14 & 2120 & & \\
SO/NA-15 & 2110 & & \\
SO/NA-16 & 2100 & & \\
SO/NA-17 & 2020 & & \\
SO/NA-18 & 2130 & 2,058 & 50 \\
SO/NA-19 & 2040 & & \\
SO/NA-20 & 2050 & & \\
SO/NA-21 & 2010 & & \\
SO/NA-22 & 2090 & & \\
SO/NA-23 & 2020 & & \\
SO/NA-24 & 2020 & & \\
Blank-1 & 0 & \\
Blank-2 & 0 & \\
Blank-3 & 0 & &
\end{tabular}

Notes:

$\mathrm{SO}=$ Sodium Oxalate

$\mathrm{SO} / \mathrm{NA}=$ Sodium Oxalate/Nitric Acid

NA Conc $=0.28$ Molar

SO Conc. $=0.1504$ Molar

$\mathrm{SO} / \mathrm{NA}$ Conc. $=0.1496$ 


\subsection{REGRESSION ANALYSIS OF MODEL CRUCIBLE DATA}

\subsection{REPORTING UNITS}

In this study, COD measurement and its usage for prediction of REDOX and control information pertinent to DWPF (i.e., feed or glass produced from simulated waste sludge) is examined. The COD analyses are reported in $\mathrm{ppm}(\mathrm{ug} / \mathrm{mL}$ or $\mathrm{mg} / \mathrm{L})$ and converted to $\mathrm{mol} / \mathrm{L}$ by dividing by the atomic weight of $\mathrm{O}_{2}$ times 1000 . Alternatively the amount of $\mathrm{O}_{2}$ can be converted to the amount of $\mathrm{C}$ as was done in the 1982 Soper reference [17] by assuming that 1 mole of carbon is equivalent to one mole of $\mathrm{O}_{2}$ because it creates one mole of $\mathrm{CO}_{2}$ (see Equation 4). The mol/L units need to be converted to $\mathrm{mol} / \mathrm{kg}$ in order to be consistent with the units used in the development of the Electron Equivalents REDOX model at the given SME wt\% solids using the SME density, as shown below.

Equation $5 \operatorname{COD}(\mathrm{mol} / \mathrm{kg}$ slurry $)=\frac{C O D(\mathrm{~mol} / \mathrm{L})}{\rho_{1}(\mathrm{~kg} / \mathrm{L})}$

$$
\text { where } \rho_{1}=\text { density at initial total solids content } T_{1}
$$

For example, at $35 \mathrm{wt} \%$ solids $\left(\mathrm{T}_{1}\right)$, the $\mathrm{SME}$ density is about $1.256 \mathrm{~kg} / \mathrm{L}$. This density value is from a correlation of density versus total solids that was derived from SRTC and DWPF data. This correlation is shown in Figure 2. The supporting data for this correlation is given in Reference 10. Because the frit does not have a COD response [17] and acts as diluent, the concentration in $\mathrm{mol} / \mathrm{kg}$ is adjusted to the SRAT wt $\%$ solids as follows:

\section{Equation 6}

$$
\operatorname{COD}^{S R A T}(\text { mol } / \mathrm{kg} \text { slurry })=\frac{\operatorname{COD}(\text { mol } / \mathrm{kg} \text { slurry })}{\left(\frac{\operatorname{SRAT} \text { slurry }(\mathrm{gms})}{\operatorname{SRAT} \text { slurry }(\mathrm{gms})+\text { FRIT }(\mathrm{gms})}\right)} \times w t \% \text { SRAT solids }
$$

This method normalizes the concentration on a 'per mass of SRAT slurry' basis. The $\mathrm{COD}^{\mathrm{SRAT}}$ (mol/kg slurry) values are given in Table 1. 
WSRC-TR-2003-00322, Rev. 0

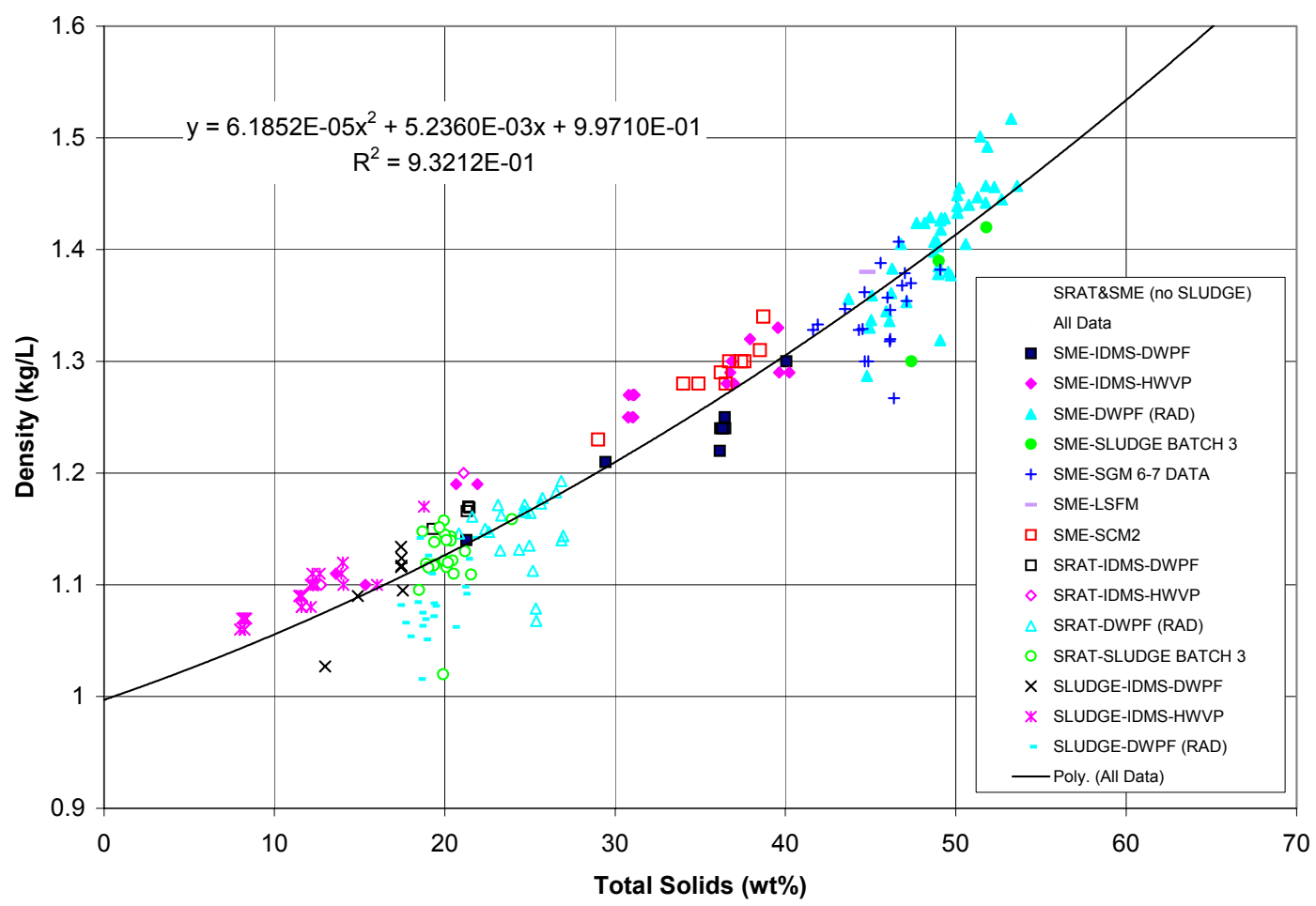

Figure 2. Density correlated to total solids.

\subsection{COD MODELING}

The independent variable (X) in the Molar Electron Equivalents ( $\xi$ ) REDOX model is a combination of concentrations as given in Equation 1, e.g. $\xi(\mathrm{mol} / \mathrm{kg}$ feed $)=2[\mathrm{~F}]+4[\mathrm{C}]$ $+4\left[\mathrm{O}_{\mathrm{T}}\right]-5[\mathrm{~N}]-2[\mathrm{Mn}]$

where $[\mathrm{F}]=$ formate $(\mathrm{mol} / \mathrm{kg}$ feed $)$

$[\mathrm{C}]=\operatorname{coal}($ carbon $)(\mathrm{mol} / \mathrm{kg}$ feed $)$

$\left[\mathrm{O}_{\mathrm{T}}\right]=$ total oxalate, soluble and insoluble $(\mathrm{mol} / \mathrm{kg}$ feed $)$

$[\mathrm{N}]=$ nitrate + nitrite $(\mathrm{mol} / \mathrm{kg}$ feed $)$

$[\mathrm{Mn}]=$ manganese $(\mathrm{mol} / \mathrm{kg}$ feed $)$

Only fifty three glasses of the $\sim 200$ fabricated were used during the development of the Electron Equivalents model (see discussion of measured REDOX acceptability and glass sample inhomogeneity in Reference 10). Of the 53 samples used to develop the REDOX correlation only 37 had COD analyses performed on them (see Table 1). The COD analyses reported are those measured before the COD procedure was modified to give a more accurate response for solid coal particles (see Section 3.3.2).

A fit of the REDOX data which includes the 53 glasses from Table 1 and 76 additional REDOX measurements from the 1997 study [16] to $\xi$ is given in Figure 3 for comparison 


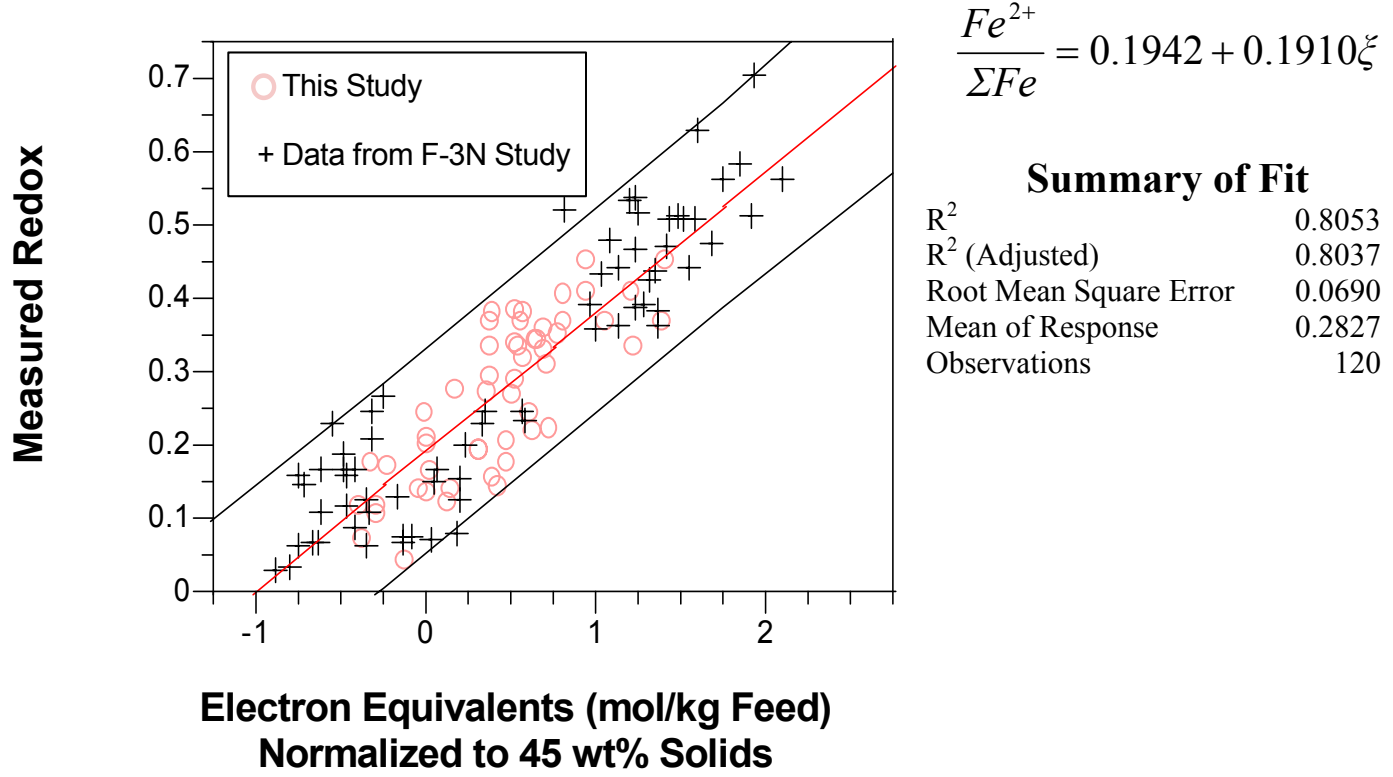

Figure 3. REDOX model with formate, oxalate, coal, nitrate, and manganese normalized for $45 \mathrm{wt} \%$ solids.

\section{Response:}

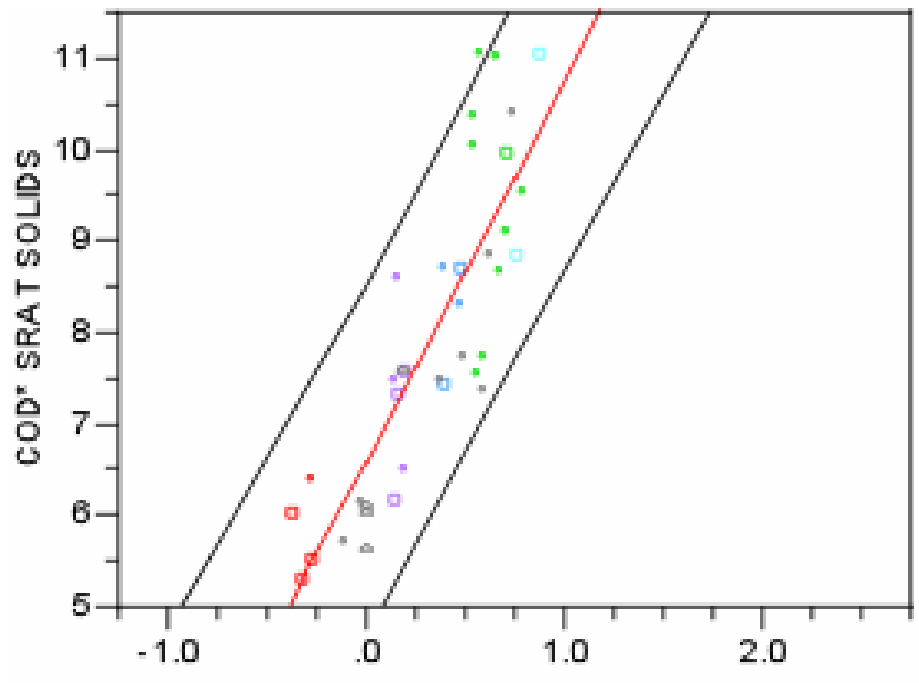

COD*SRAT Solids $=$ $6.5806+4.1357 \xi$

\begin{tabular}{lr}
\multicolumn{3}{c}{ Summary of Fit } \\
$\mathrm{R}^{2}$ & 0.7099 \\
$\mathrm{R}^{2}$ (Adjusted) & 0.7016 \\
Root Mean Square Error & 0.9291 \\
Mean of Response & 7.9663 \\
Observations & 37
\end{tabular}

Figure 4. Comparison of the Electron Equivalents to the COD response weighted by the SRAT solids. 


\section{WSRC-TR-2003-00322, Rev. 0}

to the relationship between $\xi$ and the COD response (Equation 6) in Table 1. Even though the $\xi$ range of the COD response is narrower than the range of the REDOX response, a comparison of the two figures demonstrates that the COD response is similar to the Electron Equivalents response and monitors the relative strength of the various reductants and oxidants present in the feed.

However, when the COD response is modeled against the measured REDOX, the $\mathrm{R}^{2}$ of the correlation shown in Figure 5 is not very accurate, e.g. $\mathrm{R}^{2}=0.55$. This is most likely due to the fact that the $\mathrm{Fe}^{+2} / \Sigma \mathrm{Fe}$ range (0.04-0.45) over which the COD model is fit is almost half the $\mathrm{Fe}^{+2} / \Sigma \mathrm{Fe}$ range (0.03-0.71) measured and used to develop the Electron Equivalents model.

Based on the similarity of the response of COD and the calculated electron equivalents further investigation of the COD methodology for DWPF may be warranted. The preliminary analyses presented here, based primarily on COD analyses that were measured before the procedure was modified, indicate that the COD analyses may be responding not only to the reductants in the feed but to the sum of the reductants and oxidants. This would eliminate the need for all but two measurements to predict feed REDOX (COD and SRAT wt \% solids).

\section{Response:}

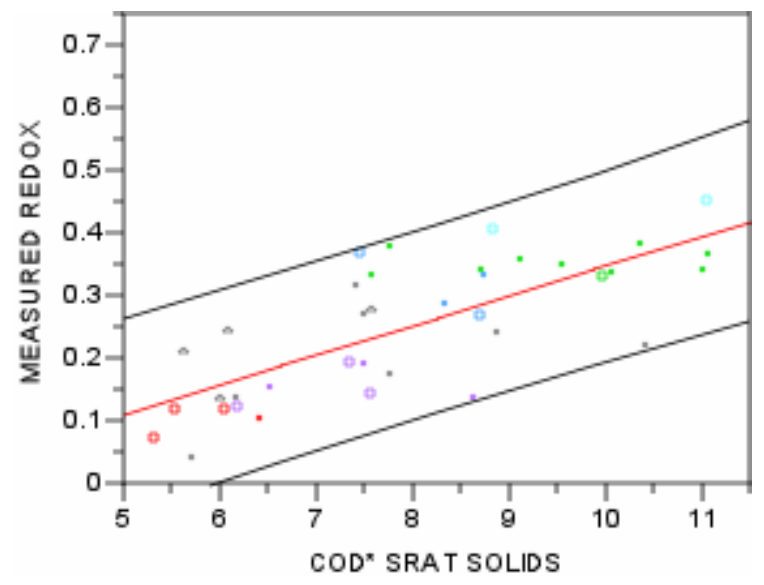

$$
\begin{aligned}
& \frac{F e^{+2}}{\Sigma F e}=-0.1293+ \\
& 0.0478 C O D * S R A T w t \%
\end{aligned}
$$

\begin{tabular}{lr}
\multicolumn{3}{c}{ Summary of Fit } \\
$\mathrm{R}^{2}$ & 0.5612 \\
$\mathrm{R}^{2}$ (Adjusted) & 0.5486 \\
Root Mean Square Error & 0.0729 \\
Mean of Response & 0.2517 \\
Observations & 37
\end{tabular}

Figure 5. Comparison of the measured REDOX to the COD response weighted by the SRAT solids $\mathrm{wt} \%$. 


\section{WSRC-TR-2003-00322, Rev. 0}

\subsection{CONCLUSIONS}

- The COD response is similar to the Electron Equivalents $(\xi)$ response indicating that COD is capable of monitoring the multiple REDuction and OXidation (REDOX) electron transfers not previously thought possible

- The COD response (based on two analytic measurements) does not track the measured $\mathrm{Fe}^{+2} / \Sigma \mathrm{Fe}$ as well as the Electron Equivalents model (based on nine analytic measurements)

- The poor COD REDOX correlation is likely due to the fact that the COD data modeled was measured before the accuracy of the COD technique was improved

- The poor COD REDOX correlation may also be because the $\mathrm{Fe}^{+2} / \Sigma \mathrm{Fe}$ data range was half the range of the data modeled with the Electron Equivalents model, e.g. COD analyses were not available for the 1997 REDOX model data used to fit the Electron Equivalents model

- Based on the similarity of the response of COD and the calculated Electron Equivalents further investigation of the COD methodology for DWPF REDOX control may be warranted.

- The particle size of the coal varied throughout the study but the COD analyses were not perfected to the point that differences in the reactivity of the coal as a function of size could be assessed. These particle sizes are larger than those currently being analyzed in the SB3 sludge. 


\section{REFERENCES}

1 B.A. Hamm, R.E. Eibling, M.A. Ebra, T. Motyka, and H.D. Martin, "High-Level Insoluble Waste Preparation for Vitrification," Sci. Basis for Nuclear Waste Management, VIII, C. M. Jantzen, et al. (Eds.), Materials Research Society, Pittsburgh, PA 793-799 (1985).

2 H.D. Schreiber, and A.L. Hockman, "Redox Chemistry in Candidate Glasses for Nuclear Waste Immobilization," Journal of the American Ceramic Society, Vol. 70, No. 8, pp. $591-594$ (1987).

3 D.S. Goldman and D.W. Brite, "Redox Characterization of Simulated Nuclear Waste Glass," J. Am. Ceram. Soc., 69 [5], pp. 411-413, (1986).

4 V. Jain, "Redox Forecasting in the West Valley Vitrification System," Ceramic Transactions, Vol. 29, Advances in the Fusion and Processing of Glass, eds., A. K. Varsheya, D. F. Bickford, and P. P. Bihuniak, pp. 523-533, (1983).

5 A.S. Choi, "Maximum Total Organic Carbon Limit for DWPF Melter Feed," U.S. DOE Report WSRC-TR-95-0119, Rev. 0, Westinghouse Savannah River Company, Aiken, SC (March 13, 1995).

6 D.F. Bickford, and A.S. Choi, "Control of High Level Radioactive Waste-Glass Melter-Part 5: Modeling of Complex Redox Effects," Proceedings of the Fifth International Symposium on Ceramics in Nuclear and Hazardous Waste Management (Eds. G.G. Wicks, D.F. Bickford, and L.R. Bunnell, Ceramic Transactions Vol. 23, American Ceramic Society, Westerville, OH, 267-279 (1991).

7 C.M. Jantzen, J.B. Pickett, K.G. Brown, T.B. Edwards, D.C. Beam, "Process/Product Models for the Defense Waste Processing Facility (DWPF): Part I. Predicting Glass Durability from Composition Using a Thermodynamic Hydration Energy Reaction MOdel (THERMO)," US DOE Report WSRC-TR93-0672, Westinghouse Savannah River Company, Aiken, SC 464p. (September, 1995).

8 C.M. Jantzen and M.J. Plodinec, "Composition and Redox Control of Waste Glasses: Recommendation for Process Control Limit," U.S. DOE Report DPST86-773, E.I. duPont deNemours \& Co., Savannah River Laboratory, Aiken, SC (November, 1986).

9 M.J. Plodinec, “Foaming During Vitrification of SRP Waste," U.S. DOE Report DPST-86-213, E.I. duPont deNemours \& Co., Savannah River Laboratory, Aiken, SC (January, 1986). 
10 C.M. Jantzen, J.R. Zamecnik, D.C. Koopman, C.C. Herman, J.B. Pickett, "Electron Equivalents Model for Controlling REDuction-OXidation (REDOX) Equilibrium During High Level Waste (HLW) Vitrification," U.S. DOE Report WSRC-TR-2003-00126, Rev. 0, Westinghouse Savannah River Company, Aiken, SC (May, 2003).

11 D.R. Click and C.J. Coleman, "Measured Coal Concentration in the First, Second and Third Samples of Mixed Tank Seven Slurry Using Loss on Ignition (LOI) and Thermal Gravimetric Analysis (TGA)," U.S. DOE Report SRT-ADS-200300005, Westinghouse Savannah River Company, Aiken, SC (October 2002).

12 W.G. Ramsey, C.M. Jantzen, and D.F. Bickford, "Redox Analyses of SRS Melter Feed Slurry; Interactions Between Formate, Nitrate, and Phenol Based Dopants," Proceedings of the 5th International Symposium on Ceramics in Nuclear Waste Management, G.G. Wicks, D.F. Bickford, and R. Bunnell (Eds.), American Ceramic Society, Westerville, OH, 259-266 (1991).

13 W.G. Ramsey, T.D. Taylor, K.M. Wiemers, C.M. Jantzen, N.D. Hutson, and D.F. Bickford, "Effects of Formate and Nitrate Content on Savannah River and Hanford Waste Glass Redox" Proceedings of the Advances in the Fusion and Processing of Glass, III, New Orleans, LA, D.F. Bickford, et.al. (Eds.) Am. Ceramic Society, Westerville, OH, 535-543 (1993).

14 W.G. Ramsey, N.M. Askew, and R.F. Schumacher, "Prediction of Copper Precipitation in the DWPF Melter from the Melter Feed Formate and Nitrate Content," U.S. DOE Report WSRC-TR-92-385, Rev. 0, Westinghouse Savannah River Company, Aiken, SC (November 30, 1994).

15 W.G. Ramsey, and R.F. Schumacher, "Effects of Formate and Nitrate Concentration on Waste Glass Redox at High Copper Concentration." U.S. DOE Report WSRC-TR-92-484, Westinghouse Savannah River Company, Aiken, SC (October 23, 1992).

16 K.G. Brown, C.M. Jantzen, and J.B. Pickett, "The Effects of Formate and Nitrate on REDuction/OXidation (REDOX) Process Control for the Defense Waste Processing Facility," U.S. DOE Report WSRC-RP-97-34, Westinghouse Savannah River Company, Aiken, SC (February, 1997).

17 P.D. Soper, "Chemical Oxygen Demand: A Technique for Evaluating Reducing Strength of Melter Feeds," U.S. DOE Report DPST-82-904, E.I. duPont deNemours \& Co., Aiken, SC (October 11, 1982).

18 ASTM, "Chemical Oxygen Demand (dichromate oxygen demand) of Waste Water," Annual Book of ASTM Standards, V.31, 543 (2004). 
19 D.F. Bickford and C.M. Jantzen, "Inhibitor Limits for Washed Precipitate Based on Glass Quality and Solubility Limits," U.S. DOE Report DPST-86-546, E.I. duPont deNemours \& Co., Aiken, SC (1986).

20 C.W. Hsu, "Defense Waste Processing Facility Nitric Acid Requirement for Treating Sludge," U.S. DOE Report WSRC-RP-92-1056, Savannah River Technology Center, Westinghouse Savannah River Co., Aiken, SC (September, 1992).

21 C.M. Jantzen, "Redox Studies and Modeling for DWPF Sludge Batch 3," U.S. DOE Report WSRC-RP-2002-00341, Rev. 0, Westinghouse Savannah River Company, Aiken, SC (August 2, 2002). 